\title{
Qualitative Analysis of Sustainability and Innovation Within the Luxury Business Sector
}

\author{
Adriana Grigorescu ${ }^{1,2}$ (D) Amalia-Elena $\operatorname{lon}^{1}$ (D)
}

Received: 21 September 2020 / Accepted: 15 September 2021 / Published online: 5 November 2021 (c) The Author(s), under exclusive licence to Springer Science+Business Media, LLC, part of Springer Nature 2021

\begin{abstract}
There is a constant discussion in the modern society regarding innovation. Everybody talks about the word, the concept, and the strategy behind it. Nonetheless, not too many companies and industries of the economy can proudly mention their use of innovation at operational level. The usage of the innovation concept is mostly linked to the idea of product improvements for commerciality and immediate returns. At the same time, sustainability occupies the second pole position behind innovation as a concept easily identifiable in numerous marketing campaigns, mostly for the beautification of phrases, rather than for business-related purposes. The question that stems here is related to our history as an innovative and sustainable civilization (to some extent), and from the difficulty of finding examples of both concepts in real-world business sectors. The present paper aims at constructing a systematic review of the previous research regarding the concepts of innovation and sustainability from a product management perspective, followed by an application to the case of the luxury apparel sector of the economy. The research could be continued through the usage of primary data, by extending the paper with state-of-the-art luxury business examples.
\end{abstract}

Keywords Innovation · Product management $\cdot$ Sustainability $\cdot$ Luxury apparel industry

Adriana Grigorescu

adriana.grigorescu@snspa.ro

Amalia-Elena Ion

amalia.ion@live.com

1 National University of Political Studies and Public Administration, 6, Povernei Street, Bucharest, Romania

2 Academy of Romanian Scientists, 54, Spl. Independentei, Bucharest, Romania 


\section{Introduction}

By studying the history of human civilization, we can all observe, step by step, how our world developed and performed across millennia. There is also the possibility of theorizing on the matter, either in the direction of the evolution being a biological process or it being indicative of a more spiritual or unearthly source. The present paper does not debate neither on anthropology, nor on ontology, but it does work with two concepts that are very much linked to our way of thinking, acting, and performing — sustainability and innovation.

The term innovation derives from the Latin word innovatus, which comprises of the meaning of renewal and change. The misuse and misinterpretation of the concept of innovation deliver confusion in implementation (Kennedy et al., 2017). Many organizations consider that by creating something new, they innovate. The matter is a bit more complex than that, and the basis for any new model, product, or service stems from its value.

The idea of sustainability, on the other hand, stems from the discussions regarding the quality of our environment, and it was not publicly heard and used of until the late 1980s (Andrew et al., 2007). It is basically a term utilized as a better replacer for the compound environmentally friendly both because it is shorter, and because it has a greater rhetorical impact. The United Nations have had a major role in promoting the concept of sustainability, of course, for clear reasons. They also underlined the importance of sustainable development equity between and within generations, proposing as a result the essence of the concept.

Personally, we view this matter more complex than simple assumptions and, therefore, the present paper will address the concept of innovation and sustainability transposed in the business sector of luxury apparel. Everything indicative of more than enough has been catalogued as luxus - the Latin word for luxury, and it has had been perceived for most of its short history as excessive (Kapferer \& Laurent, 2016), to put it lightly. Odile-Bernez (2014) has beautifully introduced the concept of economic theory in the context of the luxury industry, where starting from the eighteenth century, the latter has been rewarded a lighter connotation and it has been associated with exhilarating the senses and created feelings of fulfilment, richness, and beautification of life itself. This led to the correlation between opulence and royalty, increased social positioning and liquidity - basically luxury, and the satisfaction and mystery it incites, the high status and favourableness it provides (Kapferer, 2014; Li et al., 2012; Zhan \& He, 2012).

The Cambridge Dictionary (n.d.) defines luxury as "great comfort, especially as provided by expensive and beautiful things," while it underlines that luxury goods are "something expensive that is pleasant to have but is not necessary." At the same time, innovation comprises of new ideas, products, methods, etc., that are being translated into reality under the form of a new interpretations with favourable outcomes for the industry it addresses. Sustainability represents "the quality of causing little or no damage to the environment and therefore able to 
continue for a long time" (Cambridge Dictionary, n.d.). The three concepts are not usually found together; nevertheless, the intricate modern consumer and the ever-evolving current luxury market indicate that the latter will ultimately have to rely on such concepts in order to remain relevant to the new consumer generations, and to have consistent economic impact within its competitive ground.

Luxury has a number of characteristics, one of which being rather fundamental to the concept itself - the vagueness, the limit it sets, and the exclusiveness. Probably to carry on this last characteristic, there is not too much data on the activity of luxury brands, with the exception of general annual trend studies such as IPSOS (2019) and Bain \& Co (2019). Therefore, information regarding the usage within the luxury industry of innovative and sustainable product management strategies has also fallen behind.

Given the assembly of literature review on the topic of luxury, and focusing on integrating the principles of innovation and sustainability within the mentioned industry, we have worked on a systematic review of the previous research, in order to understand the extent to which this economic sector, with particularity the luxury clothing and accessories segment, has adhered to strategies incorporating new directions in terms of sustainable practices, and innovative processes and products. As a consequence, the curiosity of modelling a scenario in which the luxury apparel industry did adhere to some innovative and, more importantly, sustainable principles has ignited the realization of the following study. By manually gathering articles within the framework of the subject, and performing a systematic review of the former, a new perspective was unfolded. The question behind this study remains that of understanding how innovation and sustainability, two modern concepts of the economic perspective and of the modern civilization, can be included in the strategical direction of the luxury industry. The outcome, transposed under the form of a new business model for the luxury industry in general, provides important information from both perspectives of theory and practicality.

\section{Literature Review}

\section{The New Trending Concepts of Innovation and Sustainability}

Innovations continue to seize more economic sectors worldwide, with the better purpose of creating a long-term strategic plan that increases the levels and quality of competitive advantages (Gaubinger et al., 2014). In order to understand how innovation can be applied in reality, the framework of innovation management presents a set of strategic and operational tasks to be performed within the innovation process. The increases in competitiveness and the turbulence and dynamics of the business environment put considerable pressure on the firms and their ability to cope in such conditions. Markets accelerate and consumer needs shift constantly, as new patterns in consumption are being analysed. Therefore, an enterprise can only survive in such environments if it is equipped with tools for systematic innovation management and controlling innovation processes (Gaubinger et al., 2014). Fuchs and Golenhofen (2018) address the imperative and fundamental concepts of innovation, starting with 
the fact that everything changes, that change must, therefore, be anticipated, monitored, for, ultimately, to be able to adapt to change quickly enough so that you can enjoy the benefits of new. The process goes over and over, endlessly. It is, thus, agility, willingness, and high inertia that keep a business successful (Seebode et al., 2012). And all of that is engineered through the power of innovation.

By analyzing the root of the word innovation, it becomes obvious that the discussion will involve the idea of novelty, and not just a scratch at the surface, but a deep change in the business and organizational structure and/or in the product technology. Innovation consists of four dimensions, namely technology, market dimension, organizational dimension, and the innovation environment. Therefore, innovation would imply new materials, new components and technologies, or new technique of production, from the technological dimension; it also comprises of new customer needs, new customer groups, new marketing mix, or new distribution channels, from a market perspective. Moreover, the innovation environment is determined by new sources of supply, new forms of financing, new business models, and new competitors, and the organization's dimension of innovation projects a new strategy, new organization, new responsibilities, or a new production facility. In the same time, innovation can be fundamental, disruptive, adaptive, quality improving, or it can be an imitation or a fake innovation. Observing the complexity of the innovation scheme, it is quite the challenge to find examples of such applications in the business environment of the luxury sector (Girotra \& Netessine, 2013).

In the business sector, innovation leads to change pertaining to increased market and consumer value and competitive advantages for the organizations. Andrew et al. (2007) proposes a new meaning to the concept of innovation, that of solving a problem in a new way, significantly improved compared to older versions of approaches. The significantly improved character of the innovation refers to the solution being better, faster, cheaper, easier to use, more reliable, and so on. Moreover, a problem solved through the means of innovation, either in approach - operational, or in scope - intrinsic, would ultimately change the way things are being done, being achieved. For an organization that aims at making profits, innovation will be equal to their capacity level of making money, creating liquidity and capital for the former. Improvements that are incremental or enhancements to a product or service do not pertain to the idea of innovation, because those do not lead to significant advancements in product/service value.

Eco-innovation and sustainability represent the basis for business development that improves the environmental, social, and societal quality of the business processes, as well as the products and services of the enterprise (Johansson, 2008; Sezen \& Cankaya, 2013). Having a lack of clear understanding of a business model that could exploit the advantages of innovation and sustainability is the major obstacle, as sustainable innovations will never fit the logic of an already established business model (Schaltegger et al., 2012; Hansen et al., 2009). By using proactive strategies for sustainability, the enterprise can profit from the systematic transformation of its frameworks and processes. Moreover, there are studies (Ceschin \& Gaziulusoy, 2016; Gaziulusoy et al., 2013) that highlight the importance and the usability of design for sustainability, which encompasses the product innovation processes, the technical knowledge on materials, processes and energies, and the human-centred 
design knowledge. In the same time, from a policy perspective, the business sector must be motivated through environmental regulations to adhere to sustainable principles (Dangelico \& Pujari, 2010; Szekely \& Strebel, 2013).

The debate regarding sustainability is an ongoing theme since the end of the eighteenth century, with the views of Malthus. The theory of Malthus outlines the fact that increases in the world's population would outpace the growth of the subsistence means. His theory became very popular in the twentieth century, when the effects he theorized about started to appear in real-world examples. Marx and Engels have contradicted the theory of Malthus, by supporting the idea that the moral restraint is a characteristic that can be learned across all the classes of the population. They also underlined the fact that Malthus's concept does not contain in its equations the potential for social and technological growth and progress, that would, ultimately, provide for a better resource allocation and allow the world population to outgrowth the limits of its own biology. Today, economists support the ideas of Marx and Engels regarding growth and progress (Dresner, 2008), claiming that industrialized countries should reduce their per head resource consumption to a level that would create the premises for everyone on planet Earth to live indefinitely. But what if, given an environment where necessity is amped by means of luxury and decadence?

\section{The Perspective of the International Luxury Sector}

Within the luxury sector, nine segments can be identified, including personal luxury goods, luxury cars, luxury hospitality, luxury cruises, designer furniture, fine foods, fine wines and spirits, yachts, and private jets. The most lucrative segment of the luxury market - the personal luxury goods segment, which is, as a result, one of the most discussed and researched aspects of the said-market, includes luxury clothes, accessories, eyewear, and even beauty and make-up products, as the umbrella brand luxuriously advertises them all. The main purpose of these product categories is that of creating a unique value proposition to the customer base, that of covering not a tangible need, but an ego-related eccentricity.

According to some researchers (Alvarez et al., 2004; Cristini et al., 2017; Kapferer \& Laurent, 2016), there are a handful of luxury brands that appear to be involved in actions directed towards getting the attention of other consumer market segments as well, and to fall out of their comfort zone, by approaching product categories and markets with a middle-class look on the price. The future of the luxury market seems to be considerably more vulnerable to turbulences than it was used to experience, as the growing generations of new customers are being fought for by luxury brands (Husic \& Cicic, 2009), with new marketing and price strategies that definitely were not part of the standard luxury market tactic. One particular new market segment of customers for luxury goods is represented by the Asian consumers; they are the force behind the growth within the luxury industry, aiding the market globally with a mean increase cap across all segments (Bain \& Co, 2019). Chinese consumers, in particular, and Asian consumers, in general, are the mean by which the luxury market experiences sales increases (Kapferer, 2014; Li et al., 2012; Zhan \& He, 2012), as they come to represent a new typology of luxury clientele, one which endorses both 
modern and traditional values, is younger and more conspicuous than the Western luxury consumers, and purchases luxury goods to showcase their wealth and social status.

The knowledgeable new luxury consumer sent off-trail the traditional marketing of luxury goods, and suggested a new vision for the market, where the products and services no longer sell because of the charm of history that conveys the brand, but rather due to the purpose and intrinsic values of the product/service (Bain \& Co, 2019); by showcasing more vividly and fluidly how luxury can embrace the nature and create not only valuable pieces through their usage of luxurious materials, but through the creative and innovative process of making luxury out of basic materials, the luxury brands can pertain to the mainstream trend of social responsibility and sustainability in approach, a longed element by the new luxury customer in their list of consumption preferences.

The innovation and sustainability principles within the new luxury consumer segment has determined the proliferation of new business models, such as the secondhand luxury business (Ryding et al., 2018), which registered a fructuous growth in 2019, reaching the value of $€ 26$ billion (IPSOS, 2019; Bain \& Co, 2019). Although the luxury strategical direction has always been based on the idea of limited access to the market (Catry, 2003), with the growth of the global population, and the considerably higher income classes across the Globe (Kapferer, 2014; Li et al., 2012; Zhan \& He, 2012), the luxury market is witnessing an unprecedented threat of turning luxury from the individual differentiation to the mass reach, forcing the team behind product management, marketing, brand management, and also innovation processes to consider new sustainable ways of making business, avoiding the luxury market's downfall into proletariat, and losing its identity.

Given all the above related changes in the sector of luxury products/services, there is a considerable need to create structure among the studies performed so far, and to develop a generalized model for what the next period of time should represent and present for the luxury market in terms of new business models, brand management, consumer psychology and profiling, and innovation and sustainability.

\section{Research Procedure}

The qualitative analysis of the innovation and sustainability principles and tactics within the new luxury market has been performed with the usage of the systematic review instrument, by considering a number of studies on the subject, and synthesizing their results. The systematic review methodology is unfolding in a number of steps, including the formulation of the research question(s), the sourcing of relevant literature, and the evaluation of the latter, the analysis or the synthesis (where relationships are established), following by the reporting and utilization of findings (Denyer \& Tranfield, 2009). Similar research (Gurzki \& Woisetschläger, 2017) identified all the major document co-citation clusters, comprising of the most important studies within the luxury field, by investigating issues related to innovation and sustainability within the general strategical direction of the luxury business sector. 
Working as a continuation and update of the previous studies, the research question simply considers the strategical approaches of the said market, especially with the new business models arising based on the idea of innovation and sustainability principles. Considering the preview of the theoretical background on the subject of luxury market management, this paper aims at providing insight information regarding state-of-the-art approaches in the making of luxury clothing business, by assessing 48 new studies published in international journals, related to the subject of innovation and sustainability in the luxury sector. The papers were published between 2014 and 2019 in the database of Elsevier Inc. by different international journals of management, marketing, economics, and business.

Consequently, the consumer culture is one of the most important elements in the design of any strategical approach in the luxury apparel industry. It is, therefore, of paramount importance to understand, from a global perspective, how the online shopping possibilities have influenced the consumer behaviour in their buying habits, particularly for luxury apparel. We have assembled a database on the percentages of the EU population between 16 and 24 years of age - generation $\mathrm{Z}$, and 25 to 34 years of age - millennials, and their online buying behaviour during the period 2017-2019. The information has been gathered from Eurostat, and has been analysed using the econometric software Stata. The results are presented in the second section of the paper's research.

\section{The Systematic Review Process on Innovation, Sustainability, and Luxury}

Luxury is not a concept that can be easily identifiable with sustainability. Even innovation seems a bit science-fiction next to luxury, especially since luxury is a term associated with historical value, with heritage, with hand-made, rather than machine-made, with unique and limited, with costly and expensive. Those concepts seem from different worlds. Nevertheless, in a globalized world, the luxury market must cope with the expectations of its customer base, which is no longer only the bourgeoisie, and with the technological, economic, social, and political changes that are constantly happening. Thus, the certain need for a transformation of the general problem statement for the luxury industry was due to some point in time, and it happened alongside the creation of a new generation of consumers and their own input in shaping the luxury business model. That is the particular moment when the idea of sharing, borrowing, and co-purchasing (Loussaief et al., 2019) became synonymous with the luxury goods. This permanent consumption of luxury goods had to be reinterpreted, through the experiences of its customers, whom lifestyle and choices were more and more knowledgeable, informed, meaningful (Atwal \& Wiliams, 2017). So, even if the customer is mostly driven by emotion and impulse, his rationality is now important, and it can be perceived the level at which this rationality builds up on his consumption choices. Technological innovation and sustainability are now the engines pushing the process of value-creation through an efficient approach (Pantano et al., 2018). That is, therefore, the level to which a consumption decision is being made by the new luxury 
consumer. As an example, one can look closer into the situation of the Chinese industry where the focus is on innovation. The country is being pushed forward by the need for innovation, and they went thus far as to desire to change their Made in China label to Created by China (Fabre, 2014), especially transposed to the industry of luxury vehicles manufactured in this particular country, as a competitive advantage against Western luxury vehicle brands. Moreover, the process of product development in luxury fashion, for instance, has proved to be another great area for innovation (Goworek et al., 2018), more so when it is related to the relationships that are to be established along the supply chain (Pereira \& Barbieri, 2012). When it comes to innovation in retail, the flagship stores have always had the great advantage of being the perfect spot for telling a story, by playing on an innovative design (Liu et al., 2016), or by simply underlining the infinite ways in which one can bring sustainable principles into the products and services it retails — originality plus usability (Kim \& Park, 2019).

It more or less all starts with the customer, as it does in any other business, but especially so within the luxury industry. Luxury is about telling the perfect story, creating the longed-for environment the customer wants to dive into (Atwal \& Williams, 2017); it is also a place where the personal image of the customer suffers valuable add-ons, showcasing the liquidity of his transformation (Loussaief et al., 2019). Just like weather significantly influences the consumer choices and behaviours, the state of the environment, even subtle and indirect, in which the customer finds himself, can guide the perception and the notion of value of the product (Barbera et al., 2018). Marketers have, therefore, the opportunity to increase the positive consumer perception and evaluation through minor changes of the customer's environment. For luxury products and services, this basically explains why the increased price affects the perception of the consumer in a positive direction, and how the innovation in the design and ambiance of the flagship store, for instance, highlights all the characteristics of luxury products. Within the global consumer culture, there are influences from different local cultural elements (Bartikowski \& Cleveland, 2017). According to Heine et al. (2018), the country of origin principle has a significant impact on the purchasing intention of the customer for luxury items. Thus, for the segment of luxury cars in particular, the Chinese consumers experience positive brand attitudes when the label Made in China is presented/advertised (Bartikowski et al., 2019). Furthermore, the perceived quality on behalf of the customer will ultimately determine the success of the luxury car brands worldwide (Stylidis et al., 2016). Another important aspect regarding the consumer behaviour and consumer psychology is represented by trust (Bozic \& Kuppelwieser, 2019), and by being honest about the advertised product/service, the luxury brand can attain a valuable place in the consumer approach of its base segment. Within the global luxury industry, the exponential growth has been forced by new customer segments (Kapferer, 2014). The hedonic choices of this new luxury consumer (Isabella et al., 2017) form the principles and characteristics of the luxury concept (Kapferer \& Laurent, 2016). For instance, the consumer group of age 16-25, Generation Z, is not practicing the online luxury fashion shopping, as they are, apparently, not aware of this emerging practice, and finding that borrowing or sharing is the easiest and smartest way to obtain luxury outfits (Loussaief et al., 2019). On the other hand, Generation Y, or the millennials, is very brand conscious, 
and they purchase luxury products and services based on their personality dimensions and consumption motivations (Giovannini et al., 2015). As both generations will determine $130 \%$ growth to the luxury market by 2025 (Bain \& Co, 2019), it is rather important to remember that the luxury item incorporates and creates at the same time the identity of its possessor (Kessous et al., 2017), as the former must comprise of utility and artistry (Kapferer, 2014).

At the same time, innovation and sustainability can be dimly observed within concepts outside of their limits — the luxury consumer's behaviour. Specifically, for products that pertain to the segment of interactive wearable technology, the consumer is looking for both pleasure and purpose (Kim \& Park, 2019). With the neo-craft consumer segment, the luxury products incorporate characteristics such as uniqueness and craftsmanship (Kim \& Kwon, 2017), the latter being a recurring theme of the handmade label luxury market historically attributed to its products. Moreover, the luxury consumer will go long way to be remembered as a new fashion trend setter or even just in line with the new mainstream trend (Kniazeva \& Babicheva, 2017), going so far as using less admirable paths driven by their desire and need to possess the new luxury fashion product (Loureiro et al., 2018). This can only underline the results of Makkar and Yap (2018) study, where they show that the luxury market birthed a new type of shy luxury consumer, driven by emotions and self-awareness. At the same time, the effect of Schadenfreude has been observed to be related positively with counterfeited luxury products, in terms of consumer perception and behaviour, and oppositely from the original brand (Marticotte \& Arcand, 2017). The counterfeit phenomenon appears to take shape in the Middle East countries, where consumers mix original luxury brands with counterfeited ones (Pueschel et al., 2017). While consuming luxury products on the Internet, there are certain particularities that the luxury clients are searching for, especially at the esthetic level of the online platform. They need to be inspired by the ambiance of the online store, through the creation of feeling such as love and high status, while providing with the necessary information and services to satisfy their choice of platform (Quach \& Thaichon, 2017), and eventually luxury brand, which later on will be their topic for discussion within their peer circle (Shimul \& Phau, 2018).

The individuality of the luxury consumers is generally observable in their behaviour related to the luxury brands, as the consumer must experience a thorough relationship with the latter from the buying process, to the context the consumer finds himself into (Walley \& Li, 2014). The intrinsic and extrinsic luxury brand characteristics exported through luxury brand ads stand at the base of the consumer motivation and consumption differentiation (Shao et al., 2019), and, with the new trend of responsible and sustainable consumption, the experiential buying behaviour of luxury consumers is a result of six motivators (Ulusoy, 2016): the organic community, unpretentious fun, embracing the other, capabilities, challenge, and self-reflection. The behaviour of the luxury consumer suffered a mutation which makes it rather turbulent, unstable, liquid, and alongside the psychological process in which the consumer distances himself from possessions, the relationship established as a consequence between the consumer and the luxury brand can become quite thin, with no major impact on the decision-making process, free and practical (Seo \& BuchananOliver, 2017). It is a type of relationship that requires more care than it used to, it 
is frail, and the luxury brands can no longer bet only on their superiority in terms of branding and, even, quality level. The luxury industry must come up with creative ideas of making meaningful connections. With the development of the online communication channel, the luxury brand management has opened the possibility of unlimited interaction with the customer base (Checchinato et al., 2014). The story behind any luxury brand must be specific for the products/services it merchandises, as it creates elevated effective emotions of authenticity, conciseness, reversal, and humour (Chiu et al., 2012). As a result, the experiential brand strategies must be somehow encompassed in the communication and retail tactics of the luxury brand (Loussaief, 2019), and sustainability should be at the core of its brand management direction (Arrigo, 2018; Bambauer-Sachse \& Heinzle, 2018). Bartikowski and Cleveland (2017) arrived at the conclusion that the motivations and behaviours of consumers towards luxury brands cannot be presumed as globally standardized. Hence, brand management is to create this consistent brand status, by using specific positioning strategies for foreign consumers vs. local consumers (Bartikowski et al., 2019), as well as utilizing concepts such as glocal advertising (Checchinato et al., 2014). The heritage identity of the luxury brand represents one of the most important resource; its acknowledgement and utility must be linked to the present image of the brand, through its historical trajectory, achievements, meaningfulness, and nostalgia, both in relation to the consumer and in relation to its human resources (Burghausen \& Balmer, 2014). The heritage identity must justify and promise what the company and brand have to currently offer based on their experiential and sensory dimensions. At the same time, there is a certain sacralization to the heritage of a luxury brand which transfers to the stores and the marketing strategy of any luxury brand (Dion \& Borraz, 2015), under the form of a well-written, unique story made for impact on the perspectives and behaviour of customers (Chiu et al., 2012; Crettez et al., 2018), furthering the influences of each party on the other (Dogerlioglu-Demir et al., 2017). Exclusively, the luxury brand must still stay true to its history and heritage; it is to portray excellence as well as creativity (Cristini et al., 2017).

Traditional approaches in terms of strategies for brand management and marketing of luxury products do not present the same effectiveness for all the consumer segments. Apparently, the new generations of luxury consumers are not compliant with those types of advertising and retail offers (Giovannini et al., 2015), an example being the Chinese luxury consumer for whom it is more important the provenance of the luxury brand, its country of origin, rather than any other aspect of the product itself. This is a strategy for competitive differentiation and creation of consumer benefit (Heine et al., 2018). Moreover, the coherence between the consumer and the product has the potential to strengthen the promotional messages of the respective brand (Hung et al., 2017), and, in the same time, the strong relationship between the brand and the consumer is based also on the benefits provided by the brand, including the self-expressiveness ideal (Japutra et al., 2018). Kapferer (2014) noticed that any luxury brand comprises of all the elements that encompass the taste of the elites, and, it must somehow comprise also of a timeless function and scope, transforming the image of the brand and all of its products with the use of artification. The growth and development of a brand, including the luxury ones, is dependable of a good strategy (Kapferer \& Laurent, 2016). A strong luxury strategy 
comprises of differentiation stemmed from the market segmentation, which, in turn, is determined by brand identifiers and dis-identifiers (Khalifa \& Shukla, 2017). Furthermore, the cultural distance between the brand story and the local culture is not impeding the narrative-transportation process (Kim et al., 2016), but the typicality dilution explains the lack of differentiation and the confusion in parallel assessment of brands and the counterfeited cousins (Le Roux et al., 2016). The brand management of luxury products and services follows both a traditional and an unconventional path (Kim \& Kwon, 2017), with the scope of enhancing the way in which the brand is perceived (Parguel et al., 2016). Moreover, the image of the luxury brand is identified as an object of art through which the communication is established with the customer (Kniazeva \& Babicheva, 2017). Such a communication is mostly taking part within the flagship store (Liu et al., 2016), ensuring at the same time that the brand and its products are not counterfeited (Ngo et al., 2018), and that the right message is transmitted, including that of the heritage of the brand and the country of origin (Ramkumar \& Jin, 2019).

Conclusively, a luxury brand has a particular difficult road to follow, from all the possible perspectives, as traditional bets on its highest assets — prestige, heritage, sophistication, materialism, while the unconventionality of innovation and sustainability forces the break of barriers in artistry, creativity, charisma, sincerity, professionalism, but most important — utility (Semaan et al., 2019; Sung et al., 2014).

\section{The Mini-review on Online Consumer Culture}

This section of the paper addresses the capacity and behaviour of the two different luxury consumer segments that have been identified and discussed previously, namely generation $\mathrm{Z}$ and the millennials, during their online shopping spree. Eurostat has made available data on the Internet purchases by individuals, where information in percentage of the EU population of a given segment (for this research two consumer groups were used - 16-24 years of age and 25-34 years of age, consistent with the two consumer generations mentioned above) have engaged in online purchases.

Using the econometric software Stata, the research has undergone a linear regression with the scope of identifying correlations between the online purchases that amounted more than 1000 Euros, the purchases in the last 3 months, the frequency of online purchases, and the online purchases from EU sellers. The purchases of more than 1000 Euros directed towards clothes and accessories were attributed to purchases of luxury items.

Table 1 Regression results — dependent variable: online purchases of more than 1000 Euro; independent variable: last purchase online in the last 3 months

\begin{tabular}{llll}
\hline Coef & Std. err & $P$-value & $R$-squared \\
\hline 0.238 & 0.05 & 0.1 & 0.95 \\
\hline
\end{tabular}


Table 2 Regression results — dependent variable: online purchases of more than 1000 Euro; independent variable: online purchases from EU sellers

\begin{tabular}{llll}
\hline Coef & Std. err & $P$-value & $R$-squared \\
\hline 0.27 & 0.18 & 0.3 & 0.67 \\
\hline
\end{tabular}

The results of the regression (Table 1) showcase that there is significant correlation between the two variables, and their relationship is positive. The interpretation of the results underlines the fact that if the millennial generation group made one online purchase in the last 3 months, there is a $23 \%$ increase in the online purchases of more than 1000 Euro for the same consumer group.

According to the results showcased in Table 2, there is a positive, strong correlation between the two variables, presenting a $27 \%$ chance that when an online purchase is from an EU seller, the amount of the ordered products is more than 1000 Euro. Therefore, the EU sellers of luxury items represent for the millennials an incentive for their online shopping process.

In Table 3, there can be observed a positive and strong correlation between the variables, meaning that the frequency of online purchases influences the millennials towards buying products of more than 1000 Euro online. The population of millennials online shopping for products amounting more than 1000 Euro will increase by $23 \%$, as their frequency of purchasing online in the last 3 months was 6 times or more (Table 4$)$.

Generation $\mathrm{Z}$ experiences also the drive to make online purchases that amount more than 1000 Euro, but their buying behaviour is a bit more independent than that of the millennials. While for millennials, there was a $23 \%$ chance that an online shopping spree in the last 3 months was comprising of luxury items, for generation $\mathrm{Z}$, the percentage lies at 16 (Table 5).

Moreover, it seems that generation $\mathrm{Z}$ is not influenced either by the country of origin of the seller. If the millennials were incentivized to purchase online from EU seller in proportion of 27\% products that amount more than 1000 Euro, the other consumer group, generation $\mathrm{Z}$, does not comply to the same patterns (Table 6).

Generation $\mathrm{Z}$ tends to make online purchases of more than 1000 Euro as their frequency of buying online is higher, determining a $21 \%$ chance of making luxury purchases if they spend more time online and register more than 6 orders in the last 3 months.

Table 3 Regression results - dependent variable: online purchases of more than 1000 Euro; independent variable: frequency of online purchases in the last 3 months

\begin{tabular}{llll}
\hline Coef & Std. err & $P$-value & $R$-squared \\
\hline 0.23 & 0.02 & 0.06 & 0.98 \\
\hline
\end{tabular}


Table 4 Regression results - dependent variable: online purchases of more than 1000 Euro; independent variable: last purchase online in the last 3 months

\begin{tabular}{llll}
\hline Coef & Std. err & $P$-value & $R$-squared \\
\hline 0.16 & 0.09 & 0.33 & 0.75 \\
\hline
\end{tabular}

Confirmed by the mini-analysis of the two consumer groups, the buying patterns are, to some extent, different, incentivized by other triggers. Nevertheless, it needs to be reminded that the purchasing power of millennials is higher than that of generation $\mathrm{Z}$, due to the age and background difference, making this a potential influence for the given results.

\section{Results and Discussions}

The luxury market appears to be rather complicated in terms of approaches, strategies, product development, and branding. It is, therefore, mandatory to not only have insight into the mainstream consumer profiling for the luxury industry, but also to have a good understanding of the sustainable development within the luxury sector. According to the Bain \& Co. (2019), the consumers are becoming savvier and more knowledgeable regarding the products and services they want to acquire and possess, with 35\% millennials consumers and 30\% generation $\mathrm{Z}$ consumers. The two groups of luxury clientele are completely different in the way they purchase luxury goods, and the way they interact with luxury brands. By 2025, both group categories should represent more than $90 \%$ of the luxury consumers, putting the luxury industry in the situation of changing everything they used to do before, and what they believed was true before. The younger luxury consumers want to engage not only in meaningful relationships with their preferred brands, but they also expect always a bit more - sustainable design and ambiance in flagship stores, sustainable materials, innovative technology in products, creativity in what is luxury, and what will become of luxury, low-impact environmental actions and activities. The luxury business must convey to the direction imposed from its clientele, now, a very opinionated, diverse, globally reaching segment of the market. If today there are 390 million luxury consumers, in only 5 to 6 years, the number will become 450 million. With this increase in the population of the planet, the luxury market must change or adapt, at least, its branding and marketing activities in such a manner that they abide to the

Table 5 Regression results - dependent variable: online purchases of more than 1000 Euro; independent variable: online purchases from EU sellers

\begin{tabular}{llll}
\hline Coef & Std. err & $P$-value & $R$-squared \\
\hline 0.125 & 0.21 & 0.6 & 0.25 \\
\hline
\end{tabular}


Table 6 Regression results — dependent variable: online purchases of more than 1000 Euro; independent variable: frequency of online purchases in the last 3 months

\begin{tabular}{llll}
\hline Coef & Std. err & $P$-value & $R$-squared \\
\hline 0.214 & 0.04 & 0.1 & 0.96 \\
\hline
\end{tabular}

needs and wants of their ever-increasing customer base. The middle-class population, with the growth they experienced in the monthly income, is now able to buy into luxury items and services. But they might adhere to types of luxury businesses that are more approachable in terms of value-price relation, going to off-price retailers or into the new business model of second-hand luxury products for their timeless pieces. A vintage store, a fair trade, or simply a second-hand online store might be the frequented spots for the new luxury consumer. As a consequence, the luxury branding and product development must ensure they feed this true and direct relationship with their new clientele, that they not only appeal to emotion, but also to rationality, that they offer in their portfolio not just products with a label, that they diversify their channels for communication and distribution, and, lastly but not least, always show their way of including change, adaptation, and innovation in their story.

The linkage between luxury, observed and perceived by many as a moral condemnation, and innovation and sustainability, is paved by the fact that the former offers a truly sacred opportunity to the latter. According to the IPSOS, 2019 World Luxury Tracking, the pillar countries of luxury consumption are China, USA, and the European five: Germany, Great Britain, France, Spain, and Italy, with $84 \%$ of the affluent consumers getting more focused on luxury brands that encompass characteristics such as long-lasting quality, exclusivity, innovation, digitalization, and production ethics. Last year was the perfect set-up for innovation and sustainability even in the luxury industry, where, at least, from a business perspective new ways of trading luxury items, has emerged and conquered not only the real world, but also the virtual or digital version of the world. The appearance of the second-hand luxury market, the psychological and behavioural changes within the luxury client base, and the general and global need for real, natural connections have marked the beginning of a new era in the luxury industry. Sustainability was no longer a term used in the great speeches of world leaders, it became something more, an element that was searched for in every little corner of the business world. This expansion of populations, alongside the evolving general beliefs of the young consumers of luxury, has pushed the brands to do more, to reach new horizons, and to break into new modalities of making business, developing products, and creating and sustaining relationships, proving that they have the best product and brand management strategies, combining innovative and sustainable principles, to earn a place in the new stage of the luxury industry. It is quite contradictory the fact that the luxury market is approaching the idea of sustainability, as the notions are completely opposite - one symbolizing wastefulness and superficiality, and the other altruism and ethics (Arrigo, 2018). The inspiration for such a change of direction was given by the intrinsic differentiation the new luxury consumers have made in terms of social 
and environmental impact importance. Moreover, it was suggested that the flagship store represents a key element in the communication strategy of a luxury brand, and proved to be the best option for informing the consumer on the sustainability practices of the certain luxury brand, by choosing to comply the architectural design of the store with certain sustainability standards. For instance, the use of sustainable materials for furniture, that of renewable energy sources for illuminating, or substituting traditional bags with recycled paper bags or recyclable bags, alongside clear messages of corporate sustainability, in-store technology adoption/digitalization, and trained retail assistants are just a few of the elements that consumers identify as relevant for the sustainable development of a luxury brand and its environmental and social sustainability commitment.

The result of such a profound change had to leave deep marks in the framework of the business model of the luxury industry. The DNA of the market was almost completely ripped off and put back together in an unprecedented manner, while the identified consumption patterns, and general brand management strategies in the global luxury market made way for a new model to emerge. The ideals of innovation and sustainability were embraced through the optimization of the operations within the business, through the transformations and the creation of new organizational systems (Adams et al., 2015). In simple words, the luxury market and the luxury business model were replaced by actions of higher efficiency and efficacity, with products and services that are built from creativity, innovation, and value, for the ultimate purpose of building a meaningful relationship with the customer, and the desire to grab the opportunities offered by the internal advantages of the luxury market — artistry and craftsmanship.

Therefore, the new business model for the luxury industry is based on an updated value proposition for the luxury brand, which incorporates innovation and sustainability as primary elements, alongside ethical treatment, state-of-the-art technology, natural resources, local procurement of materials, consumer value co-creation, emotional and rational engagement, sincerity, unique proposition, sophistication, usability, and utility, all under an artistic and/or hand-crafted framework. The resources involved in the production and manufacturing of luxury goods must be locally procured, for sustainability and employment reasons, with the help of local craftsman and artists via partnerships that bring innovative perspective to the product development process. The main activities within the luxury business should break the boundaries, and dive into handmade manufacturing, with the utilization of recycled and left-over materials, integrating the marketing efforts of brick-and-mortar store and online digital experiences. Moreover, the luxury industry must engage proactively in sustainable waste disposal programmes, and they should use clean technologies within their processes and internal operations for sustainable reasons. The development of craftsmanship and artistry intertwined with tine R\&D department should bring a breath of fresh air for the new product development. All those activities are to be supported by a very well thought and constructed partnership portfolio, including a wide range of services - materials procurement, eco-friendly transportation, off-price retailers, vintage shops, second-hand trade fairs, and more. The above-mentioned elements are part of the structural and organizational framework 
of the business model, which shall be enhanced by the diversification of marketing and supply channels, customer segments, and relationship expansion, for the ultimate result of not only creating a unique approach, but also work on the cost structure of the business model and the revenue streams development in an efficient and effective manner. The reduction of waste by the re-usage of left-over materials would imply the minimization of costs, resulted from the implementation of innovative programmes for recycling. The revenue streams can be diversified by developing adjacent retailing offers, such as the off-price retailers, vintage shops, and second-hand trade fairs, alongside the flagship stores. With the diversification of the distribution channels; the development of online platforms for product, services, and messages deliveries; the simple and direct communication to the customer base; and the sharing of their usage of new technologies and innovations, the luxury industry will be able to better their customer relationships and to expand their customer segments. The meaningful relationships with the clientele are fuelled by the direct and individual communication and the facilitated ease of access to products and information for the consumer, with emphasis on value, and quality, having always the perspective of the final buyer as a form of feedback. The new customer segments can be acquired through the development of partnerships with the former, as the new generations of consumers (millennials and gen Z) are globally oriented, socially and environmentally aware, interested in the new technological advancements, innovations, and in the ethical and sustainable practices of the brands they love and buy into. This new perspective on the business model of the luxury industry is a statement, for it should be viewed as the normal, standard way of making business today, and not only in the luxury business, but globally. The paper can be furthered with primary data to complete the observations.

\section{Conclusion}

Considering the evolution of the global economy, and the digital and technological transformation the world has witnessed for the past 20 to 30 years; observing the acceleration of all our actions as individuals; and the cumulated actions of enterprises all over the globe, we must stop and question everything, from the frameworks to the structural and organizational processes within. The need for rediscovery and reiteration of what truly applies today in terms of strategical manoeuvres is immediate, for we must understand how this new world works, in order for us to truly become important pawns of the mechanism that is our economy.

The luxury industry is one that brings billions of Euros each year in the economy, for more and more people dream and want to be part of the bourgeoise. But luxury today, in the twenty-first century, is nothing of what it used to be. The dramatic changes in our consumer generations have radically transformed the face of this economic sector. From a psychological perspective, this study has observed numerous tendencies towards doing what is right, being ethical, moral, environmentalist, resources oriented, nurturing towards nature, raw, and willing to go long ways for the good of all. Gratefulness found its place in the decision-making process of the 
majority of individual consumers. Luxury is now, therefore, a mean through which people experience extraordinariness in their lives, but by which they are truly humbled. The value within the luxury goods represents the main characteristic by which the product itself is judged. Luxury industry has, as a consequence, the difficult job of working towards perfecting their products with artistry, crafting, innovation, and sustainability.

The current research has performed a systematic review of 48 papers around topics related to the luxury industry, for the ultimate purpose of finding the main principles that guide this economic sector in our modern world. It has been, therefore, observed that the luxury industry shed many skins, and it is in some areas unrecognizable, that it must be supported by business models and strategies that are updated to the needs of a transforming market, with lots of innovations and creative ways of internal and external sustainable processes and relationships. A more sincere and direct approach of the customer base, a stable and long-lasting partnership with local supplier and manufacturer, a truthful message shared with the world, a veritable innovative product, and a business model that screams sustainability are some of the elements that must be, at least to some extent, identifiable within the approach of any luxury brand active on the present market.

The limitations of the study have been the usage of only secondary data, but, as this research can be extended, that can be also interpreted as a first step into the discovery of the new trend in the luxury industry. Moreover, it would be rather fascinating, as well as very insightful to observe real-business case studies from the said market, and add that information to further the research. Even though there are still elements that could not be understood from this first attempt, the present paper has brought to light some interesting information regarding the general direction of this economic sector, as well as the changes that pop up more commonly and rapidly lately in fields related to that of luxury sector such as consumer psychology, innovation management, sustainability, and business modelling.

It is, therefore, our mission to better understand the world we live in, and, little by little, to share our knowledge, become more practical and truthful, just like the luxury industry has been forced to adapt to a unique transformation, by overcoming its barriers with the usage of unconventional means such as artistry, creativity, innovation, and sustainability.

\section{Update - The Impact of the COVID-19 Pandemic on the Luxury Industry}

The impact of the pandemic has been felt across the globe in a matter of weeks. The world's economy was hit by this tsunami, and it completely changed the way in which human beings perform their daily tasks and activities. It is only obvious that the luxury industry felt the influence of the new world order, and it all started with the consumer behaviour.

According to a Google Trend research from June 22, 2020, written by Lucy Sinclair (2020), the consumer behaviour, apart from moving completely to the online medium, has changed in the direction of searching for the proactive response and action from different brands. People were interested to learn more about the 
world situation, and they were driven to donate to different causes. Moreover, the overall direction of the consumer behaviour has been shifted towards shopping either online, or 'nearby'; people tend, during the pandemic, to shop locally. In terms of online resources and inspiration, people have been actively interested in searching for projects that could be developed at home, and to create décor items or DIY items. Although travelling has been forbidden or limited, people have continued to search for new ways of entertainment by upgrading their home and garden. Moreover, the online activity of the millennials and generation $\mathrm{Z}$ has increased almost $70 \%$ from the period before the COVID-19 crisis (Global Web Index, 2020).

Due to the movement on the online platforms, a huge amount of data has been collected, and luxury brands have had the opportunity to learn more about their consumers. Although the main interest of the consumers was not particularly directed towards purchasing luxury items, they were very much interested into living new digital experiences, and could be perceived as a starting point in the new strategic direction of the luxury industry.

First of all, the luxury shoppers have moved to the online platforms for purchasing luxury apparel, and, even though, it might not be sure that this $20 \%$ increase in the online luxury purchases will be maintained or increased after the confinement measures will be relaxed; it is clear that luxury consumers are ready to experience the digital possibilities of online purchases. Affluent consumers, who already were accustomed to online luxury shopping sprees, diversified their luxury purchases in terms of products, and of brands. Generally, the luxury consumers have also been interested in making their living conditions even more comfortable, and they have engaged in home luxury online purchases.

Even if this situation has brought people back to the essentials, once people have attained the level of comfort they were searching for, they started to concentrate on shopping for luxury items. Secondly, what it is very important for Gen $\mathrm{Z}$ and the millennials in this time is for luxury brands to create a sense of closure, and to continue to communicate with their customers. The need for connection and the drive towards solidarity should be elements within the strategic direction of the luxury brands even after the safety measures will be relaxed. The rebranding of the luxury industry in this direction will increase the loyalty of the consumers on the long run. For example, LVMH has started to produce hand sanitizers and face masks to answer the consumer needs and increase brand loyalty.

Thirdly, this period represents an opportunity for smaller luxury businesses to attain the consumer awareness and interest towards their products.

At the same time, consumers are searching for products that are carefully designed to respond to new essentials and new realities. Therefore, a luxury brand that designs its products keeping in mind the healthy living desire of its consumers will manage to build brand affinity. For instance, the activewear brands for men and women have experienced an exploding growth in purchases during the COVID-19 pandemic (Beauloye, 2020).

Furthermore, in terms of marketing, luxury brands have adapted their messages to the pandemic situation. Ted Baker has used online advertorials with images that 
pertain to activities that are to be performed indoors, and for products, including apparel, that are destined for indoor activities.

As underlined previously in this study, the millennials and generation $\mathrm{Z}$ are very attentive to luxury brands that communicate transparently, and that are engaged in sustainable activities or that work based on sustainable values and principles. Understanding the concern of their consumers for safety and security, LVMH has constantly posted messages to their customer base reassuring them that their activities are sustainable, and that their main scope is keeping their products in line with the need for health and safety of the population.

Some luxury brands, such as Loewe En Casa, have created new ways for entertaining the consumer, and, at the same time, to showcase their craftsmanship and artistry, with the use of online events and workshops. Such an approach, but with a different instrument, has managed to implement also Ted Baker, by creating an online hub for at home activities, including gym workouts or puzzles, while Bulgari and Dior launched online VR showrooms for their products.

Overall, the luxury industry has felt financially the blow of the pandemic across the globe, but at the same time has been taught how to respond to the challenge. With their resources, many luxury apparel brands have managed to offer not only their usual products to their consumers, but they have introduced virtual experiences, with updated, transparent messages, and developed a more consistent and close relationship with their main consumers - the millennials and generation $\mathrm{Z}$. It is clear that the future will still remain rooted in the online medium, and the luxury industry must follow that trend. Moreover, the luxury industry has to quickly respond to the lifestyle changes of their consumers, and to follow-up with marketing strategies that underline sustainability, value, quality, and safety. It has been a challenging new world, but, overall, it bears a lot of opportunities.

\section{References}

Adams, R., Jeanrenaud, S., Bessant, J., Denyer, D., \& Overy, P. (2015). Sustainability-oriented innovation: A systematic review. International Journal of Management Reviews, 18(2), 180-205.

Alvarez, G., Kemanian, V., \& Malnight, T. (2004). Keeping the strategic balance in the new luxury market. Critical Eye, 9(11), 43-47.

Andrew, J. P., et al. (2007). Payback: Reaping the rewards of innovation. Harvard Business School Press.

Arrigo, E. (2018). The flagship stores as sustainability communication channels for luxury fashion retailers. Journal of Retailing and Consumer Services, 44, 170-177.

Atwal, G., \& Williams, A. (2017). Luxury brand marketing — The experience is Everything! Advances in Luxury Brand Management, 43-57.

Bain \& Co. (2019). Luxury Goods Worldwide Market Study, Spring 2019. Retrieved from https://altagamma. it/media/source/Altagamma\%20Bain\%20Worldwide\%20Market\%20Monitor_update\%202019.pdf

Bambauer-Sachse, S., \& Heinzle, P. (2018). Comparative advertising for goods versus services: Effects of different types of product attributes through consumer reactance and activation on consumer response. Journal of Retailing and Consumer Services, 44, 82-90.

Barbera, M., Northey, G., Septianto, F., \& Spanjaard, D. (2018). Those prices are HOT! How temperature-related visual cues anchor expectations of price and value. Journal of Retailing and Consumer Services, 44, 178-181.

Bartikowski, B., \& Cleveland, M. (2017). "Seeing is being": Consumer culture and the positioning of premium cars in China. Journal of Business Research, 77, 195-202. 
Bartikowski, B., Fastoso, F., \& Gierl, H. (2019). Luxury cars made-in-China: Consequences for brand positioning. Journal of Business Research. https://doi.org/10.1016/j.jbusres.2019.01.072

Beauloye, F. E. (2020). Luxury and the new stay-at-home economy: A new paradigm. LUXE Digital Report. Retrieved from: https://luxe.digital/business/digital-luxury-reports/stay-at-home-luxury/

Bozic, B., \& Kuppelwieser, V. G. (2019). Customer trust recovery: An alternative explanation. Journal of Retailing and Consumer Services, 49, 208-218.

Burghausen, M., \& Balmer, J. M. T. (2014). Corporate heritage identity management and the multi-modal implementation of a corporate heritage identity. Journal of Business Research, 67(11), 2311-2323.

Catry, B. (2003). The great pretenders: The magic of luxury goods. Business Strategy Review, 14(3), $10-17$.

Ceschin, F., \& Gaziulusoy, I. (2016). Evolution of design for sustainability: From product design to design for system innovations and transitions. Design Studies, 47, 118-163. https://doi.org/10. 1016/j.destud.2016.09.002

Checchinato, F., Colapinto, C., \& Giusto, A. (2014). Advertising in the luxury sector in China: standardisation or adaptation? A comparison between China and Italy. The Globalization of Chinese Business, 241-264.

Chiu, H.-C., Hsieh, Y.-C., \& Kuo, Y.-C. (2012). How to align your brand stories with your products. Journal of Retailing, 88(2), 262-275.

Crettez, B., Hayek, N., \& Zaccour, G. (2018). Brand imitation: A dynamic-game approach. International Journal of Production Economics, 205, 139-155.

Cristini, H., Kauppinen-Räisänen, H., Barthod-Prothade, M., \& Woodside, A. (2017). Toward a general theory of luxury: Advancing from workbench definitions and theoretical transformations. Journal of Business Research, 70, 101-107.

Dangelico, R. M., \& Pujari, D. (2010). Mainstreaming green product innovation: Why and how companies integrate environmental sustainability. Journal of Business Ethics, 95(3), 471-486. https://doi. org/10.1007/s10551-010-0434-0

Denyer, D., \& Tranfield, D. (2009). Producing a systematic review. In D. Buchanan \& A. Bryman (Eds.), The sage handbook of organizational research methods (pp. 671-689). Sage.

Dion, D., \& Borraz, S. (2015). Managing heritage brands: A study of the sacralization of heritage stores in the luxury industry. Journal of Retailing and Consumer Services, 22, 77-84.

Dogerlioglu-Demir, K., Tansuhaj, P., Cote, J., \& Akpinar, E. (2017). Value integration effects on evaluations of retro brands. Journal of Business Research, 77, 124-130.

Dresner, S. (2008). The principles of sustainability. Earthscan.

Fabre, G. (2014). The Real Leap Forward: China's R\&D and innovation strategy. The Globalization of Chinese Business, 3-25.

Fuchs, C., \& Golenhofen, F. J. (2018). Mastering disruption and innovation in product management: Connecting the dots. Springer International Publishing AG.

Gaubinger, K., Rabl, M., Swan, S., \& Werani, T. (2014). Innovation and Product Management. Springer.

Gaziulusoy, A. İ, Boyle, C., \& McDowall, R. (2013). System innovation for sustainability: A systemic double-flow scenario method for companies. Journal of Cleaner Production, 45, 104-116. https:// doi.org/10.1016/j.jclepro.2012.05.013

Giovannini, S., Xu, Y., \& Thomas, J. (2015). Luxury fashion consumption and Generation Y consumers. Journal of Fashion Marketing and Management: An International Journal, 19(1), 22-40.

Girotra, K., \& Netessine, S. (2013). OM forum-Business model innovation for sustainability. Manufacturing \& Service Operations Management, 15(4), 537-544. https://doi.org/10.1287/msom.2013. 0451

Global Web Index. (2020). Coronavirus Research - July 2020. Multi-market research wave 5. Retrieved from: https://www.globalwebindex.com/hubfs/1.\%20Coronavirus\%20Research\%20PDFs/GWI\%20coronavirus\% 20findings\%20July\%202020\%20-\%20Multi-Market\%20Research\%20(Release\%2011).pdf

Goworek, H., Oxborrow, L., Claxton, S., McLaren, A., Cooper, T., \& Hill, H. (2018). Managing sustainability in the fashion business: Challenges in product development for clothing longevity in the UK. Journal of Business Research. https://doi.org/10.1016/j.jbusres.2018.07.021

Gurzki, H., \& Woisetschläger, D. M. (2017). Mapping the luxury research landscape: A bibliometric citation analysis. Journal of Business Research, 77, 147-166.

Hansen, E. G., Grosse-Dunker, F., \& Reichwald, R. (2009). Sustainability innovation cube - A framework to evaluate sustainability-oriented innovations. International Journal of Innovation Management, 13(04), 683-713. https://doi.org/10.1142/s1363919609002479 
Heine, K., Atwal, G., \& He, J. (2018). Managing country-of-origin affiliations for luxury brand-building in China. Australasian Marketing Journal (AMJ). https://doi.org/10.1016/j.ausmj.2018.09.001

Hung, Y. C., Song, L., Chao, C. W. F., \& Guan, C. (2017). Love at first sight: The effect of presentation order on evaluation of experiential options in luxury tour packages. Journal of Business Research, 81, 181-191.

Husic, M., \& Cicic, M. (2009). Luxury consumption factors. Journal of Fashion Marketing and Management: An International Journal, 13(2), 231-245.

IPSOS. (2019). World Luxury Tracking 2019. Retrieved from https://www.ipsos.com/en/world-luxurytracking-2019

Isabella, G., Mazzon, J. A., \& Dimoka, A. (2017). Impacts of product type and representation type on the perception of justice and price fairness. Journal of Business Research, 81, 203-211.

Japutra, A., Molinillo, S., \& Wang, S. (2018). Aesthetic or self-expressiveness? Linking brand logo benefits, brand stereotypes and relationship quality. Journal of Retailing and Consumer Services, 44, 191-200.

Johansson, G. (2008). Product innovation for sustainability: On product properties for efficient disassembly. International Journal of Sustainable Engineering, 1(1), 32-41. https://doi.org/10.1080/ 19397030802113835

Kapferer, J.-N. (2014). The artification of luxury: From artisans to artists. Business Horizons, 57(3), 371-380.

Kapferer, J.-N., \& Laurent, G. (2016). Where do consumers think luxury begins? A study of perceived minimum price for 21 luxury goods in 7 countries. Journal of Business Research, 69(1), 332-340.

Kennedy, S., Whiteman, G., \& van den Ende, J. (2017). Radical innovation for sustainability: The power of strategy and open innovation. Long Range Planning, 50(6), 712-725. https://doi.org/10.1016/j. 1rp.2016.05.004

Kessous, A., Valette-Florence, P., \& De Barnier, V. (2017). Luxury watch possession and dispossession from father to son: A poisoned gift? Journal of Business Research, 77, 212-222.

Khalifa, D., \& Shukla, P. (2017). Me, my brand and I: Consumer responses to luxury brand rejection. Journal of Business Research, 81, 156-162.

Kim, J.-E., Lloyd, S., \& Cervellon, M.-C. (2016). Narrative-transportation storylines in luxury brand advertising: Motivating consumer engagement. Journal of Business Research, 69(1), 304-313.

Kim, H. Y., \& Kwon, Y. J. (2017). Blurring production-consumption boundaries: Making my own luxury bag. Journal of Business Research, 74, 120-125.

Kim, J., \& Park, E. (2019). Beyond coolness: Predicting the technology adoption of interactive wearable devices. Journal of Retailing and Consumer Services, 49, 114-119.

Kniazeva, M., \& Babicheva, E. (2017). (Un)saving face, or the designer face as a new consumer commodity. Journal of Business Research, 74, 143-148.

Le Roux, A., Bobrie, F., \& Thébault, M. (2016). A typology of brand counterfeiting and imitation based on a semiotic approach. Journal of Business Research, 69(1), 349-356.

Li, G., Li, G., \& Kambele, Z. (2012). Luxury fashion brand consumers in China: Perceived value, fashion lifestyle, and willingness to pay. Journal of Business Research, 65(10), 1516-1522.

Liu, S., Perry, P., Moore, C., \& Warnaby, G. (2016). The standardization-localization dilemma of brand communications for luxury fashion retailers' internationalization into China. Journal of Business Research, 69(1), 357-364.

Loureiro, S. M. C., de Plaza, M. A. P., \& Taghian, M. (2018). The effect of benign and malicious envies on desire to buy luxury fashion items. Journal of Retailing and Consumer Services. https://doi.org/ 10.1016/j.jretconser.2018.10.005

Loussaïef, L., Ulrich, I., \& Damay, C. (2019). How does access to luxury fashion challenge self-identity? Exploring Women's Practices of Joint and Non-Ownership. Journal of Business Research. https:// doi.org/10.1016/j.jbusres.2019.02.020

Makkar, M., \& Yap, S.-F. (2018). Emotional experiences behind the pursuit of inconspicuous luxury. Journal of Retailing and Consumer Services, 44, 222-234.

Marticotte, F., \& Arcand, M. (2017). Schadenfreude, attitude and the purchase intentions of a counterfeit luxury brand. Journal of Business Research, 77, 175-183.

Ngo, L. V., Northey, G., Tran, Q., \& Septianto, F. (2018). The Devil might wear Prada, but Narcissus wears counterfeit Gucci! How social adjustive functions influence counterfeit luxury purchases. Journal of Retailing and Consumer Services. https://doi.org/10.1016/j.jretconser.2018.09.003

Odile-Bernez, M. (2014). Comfort, the acceptable face of luxury: An eighteenth-century cultural etymology. Journal for Early Modern Cultural Studies, 14(2), 3-21. 
Pantano, E., Priporas, C.-V., \& Stylos, N. (2018). Knowledge Push Curve (KPC) in retailing: Evidence from patented innovations analysis affecting retailers' competitiveness. Journal of Retailing and Consumer Services, 44, 150-160.

Parguel, B., Delécolle, T., \& Valette-Florence, P. (2016). How price display influences consumer luxury perceptions. Journal of Business Research, 69(1), 341-348.

Pereira de Carvalho, A., \& Barbieri, J. C. (2012). Innovation and sustainability in the supply chain of a cosmetics company: A case study. Journal of Technology Management \& Innovation, 7(2), 144156. https://doi.org/10.4067/s0718-27242012000200012

Pueschel, J., Chamaret, C., \& Parguel, B. (2017). Coping with copies: The influence of risk perceptions in luxury counterfeit consumption in GCC countries. Journal of Business Research, 77, 184-194.

Quach, S., \& Thaichon, P. (2017). From connoisseur luxury to mass luxury: Value co-creation and codestruction in the online environment. Journal of Business Research, 81, 163-172.

Ramkumar, B., \& Jin, B. E. (2019). Examining pre-purchase intention and post-purchase consequences of international online outshopping (IOO): The moderating effect of E-tailer's country image. Journal of Retailing and Consumer Services, 49, 186-197.

Ryding, D., Henninger, C. E., \& Cano, M. B. (2018). Vintage luxury fashion: Exploring the rise of the secondhand clothing trade. Palgrave Macmillan.

Schaltegger, S., Lüdeke-Freund, F. \& Hansen, E. G. (2012). Business cases for sustainability: The role of business model innovation for corporate sustainability. International Journal of Innovation and Sustainable Development, 2012, Vol. 6, No. 2, pp. 95-119. Available at: https://www.inderscienceonline. com/doi/abs/10.1504/IJISD.2012.046944

Seebode, D., Jeanrenaud, S., \& Bessant, J. (2012). Managing Innovation for Sustainability. R\&d Management, 42(3), 195-206. https://doi.org/10.1111/j.1467-9310.2012.00678.x

Semaan, R. W., Ashill, N., \& Williams, P. (2019). Sophisticated, iconic and magical: A qualitative analysis of brand charisma. Journal of Retailing and Consumer Services, 49, 102-113.

Seo, Y., \& Buchanan-Oliver, M. (2017). Constructing a typology of luxury brand consumption practices. Journal of Business Research. https://doi.org/10.1016/j.jbusres.2017.09.019

Sezen, B., \& Çankaya, S. Y. (2013). Effects of green manufacturing and eco-innovation on sustainability performance. Procedia - Social and Behavioral Sciences, 99, 154-163. https://doi.org/10.1016/j. sbspro.2013.10.481

Shao, W., Grace, D., \& Ross, M. (2019). Investigating brand visibility in luxury consumption. Journal of Retailing and Consumer Services, 49, 357-370.

Shimul, A. S., \& Phau, I. (2018). Consumer advocacy for luxury brands. Australasian Marketing Journal $(A M J)$. https://doi.org/10.1016/j.ausmj.2018.05.016

Sinclair, L. (2020). Search insights to help you understand consumer needs in uncertain times - 22 June 2020 edition. Retrieved from: https://www.thinkwithgoogle.com/intl/en-cee/insights-trends/researchdata/covid-shopping-behaviour-insights/.

Stylidis, K., Burnap, A., Rossi, M., Wickman, C., Söderberg, R., \& Papalambros, P. Y. (2016). A preliminary study of trends in perceived quality design attributes in the automotive luxury market segment. International Design Conference - Design 2016, Dubrovnik, Croatia; Industrial Design, 2189-2196.

Sung, Y., Choi, S. M., Ahn, H., \& Song, Y.-A. (2014). Dimensions of luxury brand personality: Scale development and validation. Psychology \& Marketing, 32(1), 121-132.

Szekely, F., \& Strebel, H. (2013). Incremental, radical and game-changing: Strategic innovation for sustainability. Corporate Governance: THe International Journal of Business in Society, 13(5), 467481. https://doi.org/10.1108/cg-06-2013-0084

Ulusoy, E. (2016). Experiential responsible consumption. Journal of Business Research, 69(1), $284-297$.

Walley, K., \& Li, C. (2014). The market for luxury brands in China: Insight based on a study of consumer's perceptions in Beijing. Journal of Brand Management, 22(3), 246-260.

Zhan, L., \& He, Y. (2012). Understanding luxury consumption in China: Consumer perceptions of bestknown brands. Journal of Business Research, 65(10), 1452-1460.

Publisher's Note Springer Nature remains neutral with regard to jurisdictional claims in published maps and institutional affiliations. 